DOI https://doi.org/10.18551/rjoas.2018-09.45

\title{
FACTORS AFFECTING THE PERFORMANCE OF SUPERVISION CONSULTANT ON THE TIME AND QUALITY OF MARKET REVITALIZATION WORK IN TULUNGAGUNG DISTRICT
}

\author{
Azis Subandiyah, Novianto Erwin* \\ Civil Engineering Majoring Construction Management, National Institute of Technology, \\ Malang, Indonesia \\ *E-mail: cup.subandiyah@ymail.com \\ ORCID: 0000-0001-8858-567X
}

\begin{abstract}
This research is conducted to determine the factors directly or indirectly affecting the performance of supervision consultant on the time and quality of market revitalization work in Tulungagung District and to get the most dominant factors affecting it. Data analysis method used is factor analysis and Path analysis of the answers from questionnaires distributed to 41 respondents including the contractor and the owner involved in the market revitalization work. Based on the findings of the research, all factors have an effect directly or indirectly and simultaneously on the time target. Individually, the factors that have significant effect on the time target are Interaction and Coordination Skills, Adequacy of Resources, and Capability. The factors that have significant effect on the quality target are Interaction and Coordination Skills, Adequacy of Resources, Capability, and Time Target on the Quality target; either directly and indirectly through Time Target. The most dominant factor affecting the failure in achieving the time target and quality target is the Adequacy of Resources. The strategy to overcome this is that the consultant must immediately increase the number of personnel so that the project can be implemented in accurate time and accurate quality. Further research is expected to add other variables such as discipline, quality control, and supervision variables and pay more attention to those indicators.
\end{abstract}

\section{KEY WORDS}

Performance, consultant, time, quality.

The construction of traditional markets is one of the priorities for infrastructure development promoted by the Government. This is in line with the Nawa Cita Program promoted by the President of the Republic of Indonesia, Joko Widodo, who will conduct the construction of 1000 markets per year. The revitalization of traditional market is carried out thoroughly in each district and city in 33 provinces in a gradual and sustainable manner based on the priority scale and needs of each region. Similarly, in Tulungagung District, in the fiscal year of 2015, it allocated a budget of 30 billion rupiah which was divided into 12 activity packages in which each year plans to increase the budget for the revitalization of the traditional market.

The market revitalization in Tulungagung District, which was built in the fiscal year of 2015 , is expected to produce buildings that are in accordance with the planning in accurate time, accurate quality, and accurate cost. Certainly, it is also inseparable from the role and performance of the contractors and supervision consultants who provide expert services to the owner or assignor; in this case represented by the Commitment Making Officer and assisted by the Technical Development Team.

However, in its implementation, many problems occur in the field. For example, the owner has entrusted the full responsibility for supervision in the field to the supervision consultant. However, the supervision consultant has not carried out the duties and responsibilities of the supervision as well as possible. There are several packages of activities that experience delays or get less than expected quality due to less than optimal supervision. 
The main indicator of the success of a project is the completion of the project in accurate time and accurate quality based on the predetermined planning (Chan and Chan, 2004). Failure in achieving accurate time and quality can be considered as a failure of a construction project, so the supervision consultant plays a very important role in the success of the project in accurate time and quality (Arditi and Patel, 1989).

To improve the professionalism of the supervision consultants, the handling of course cannot be conducted partially. However, this process requires a thorough improvement. These improvement efforts must be based on the right vision, mission and strategy. Therefore, monitoring the performance of the supervision consultant is very important.

The factors assumed to be affecting the performance of the supervision consultant on the time and quality of market revitalization in Tulungagung District are an Understanding of Contract Documents and Understanding of Technical Specifications, Interaction and Coordination Skills, Commitment and Flexibility, Adequacy of Resources, Experience, Capability And Motivation.

\section{THEORETICAL FRAMEWORK}

The project is a non-repetitive activity with limited time and resources to achieve a predetermined end result, for example a product or production facility. Project activities can be interpreted as a temporary activity that lasts for a limited period of time, with the allocation of certain resources which are intended to produce products or deliverables whose quality criteria have been clearly outlined (Suharto, 2001).

Project management is an effort to achieve goals that have been clearly defined and determined as efficiently and effectively as possible. To achieve these goals, it requires resources including human resources which are the key to everything (Nugraha, 1985).

Supervision is an examination of the use of governance that applies in the execution of tasks to avoid deviations. Another understanding of supervision is an attempt to evaluate project data/ facts accompanied by authority in implementing SOPs in providing the Instruction to Take Actions (PT3).

The Materials to Take Actions are the follow-up of the Instruction to Take Actions, among others, about the discipline of the project progress both in terms of financial, time, and physical, and giving rewards/ sanctions to the executors based on the prevailing laws and regulations.

In addition, the implementation of supervision is the realization of the planning and delegation of the existing authority systems so that the work patterns and organizational structure will be tested in the implementation.

The scope of supervision consultant task provide expert services to the owner or assignor; in this case represented by the Commitment Making Officer and assisted by the Technical Development Team in carrying out the tasks of coordination and control of all development technical activities starting from the design stage to the construction implementation stage and the maintenance period; either concerning the aspects of management, technology, and engineering.

The basic objective of supervision is to obtain work results that are able to achieve the objectives, including: Accurate quality; Accurate time; Accurate cost; Accurate benefit.

The results of the recording of all inspections are compiled for the purpose of reporting and taking corrective actions, i.e. actions that need to be taken and if necessary, doing improvements and accommodating unexpected situations immediately, and correcting irregularities in the work.

Some principles of supervision include:

- Principle of the objectives. The objective of the supervision function is to facilitate the achievement of organizational objectives. Supervision is not a fictitious activity, but it is directly concerned with efforts to meet the demands of a predetermined standard.

- Principle of standard setting. In order to make the supervision function to be effective, an objective, careful, and harmonious standard with specific circumstances must be established. 
- Principle of determining the points of strategic supervision. The purpose of determining the main points of strategic supervision is to monitor the work activities that are carried out.

- Principle of corrective action. Supervision can be economically justified when measurements are taken to correct actual deviations or potential irregularities that come from the plan.

- Principle of management with the exception. The most important supervisor's task is to trace and find potential and real deviations from the plan that has been formulated at the right time so that corrective actions can be taken.

- Principle of supervision flexibility. Supervision, similar to the plan, the basis of supervision must be designed with high flexibility to deal with the changing conditions and circumstances.

- Principle of organizational harmony. Efficiently designed supervision must be in harmony with the organizational structure.

- Principle of supervision suitability. The supervision function must reflect the positionaccording to the design - that must be carried out in which it must be in accordance with the needs of each manager.

- Principle of supervision responsibility. Since the main responsibility for carrying out the supervision lies with the supervisor, then logically, it can be concluded that supervision of the work is under supervisor's control.

- Principle of supervision accountability. Various types of management supervision centers are ways to maintain the assumption that managers remain responsible for the results of implementation.

It covers activities of supervision tasks carried out by project owners and consultants in carrying out work related to construction which consists of:

- Examine and study contract documents that will be used as the basis for supervision tasks.

- Supervise the implementation of material usage, the use of equipment and method of implementation and supervise the time and financing accuracy of the construction.

- Supervise the implementation of construction from the aspects of quality, quantity and rate in achieving work volume.

- Conduct the inventory of changes and adjustments that must be carried out in the field according to the arising problems.

- Conduct regular field meetings and make weekly and monthly periodic supervision work reports made by the contractor.

- Draw up the official report of the progress for the approval of installment payments, maintenance of work, as well as handing over of the results of the first and second jobs.

- Check the work preparation/ field administration (reports, pictures, schedules and so on).

- Observe images that are in accordance with the work carried out in the field (as built drawing) before the first handover.

- Draft the damage to maintenance and supervise its repairs.

- Conduct mutual checks that have been agreed upon in the field.

- Supervise procedures/ work rules during the implementation of construction.

- Coordinate during construction.

- Conduct supervision guidance at each site, collect work progress reports, and make notes to control progress.

The performance of consultant is a result of work achieved by a consultant in carrying out tasks that are charged to him/her which are based on skills, experience, sincerity, and time.

Performance is a condition that must be known and confirmed to certain parties to determine the level of achievement of an agency which is linked to the vision carried out by 
an organization or company and to know the positive and negative impacts of an operational policy (Suharto, 2001).

Market is a place where buyers and sellers meet to make a sale and purchase transaction of goods or services. According to Economics, the definition of market relates to its activities not its place (Slater et. al., 2010). One characteristic of a market is the existence of transaction or buying and selling activities (Churchill and lacobucci, 2006). Consumers come to the market to shop with money to pay the specified price. Stanton expressed a broader definition of the market (Cowan et. al., 2013)

Stanton mentioned that markets are people who have desire to be satisfied, money to shop, and willingness to spend it. Thus, based on this definition, there are factors supporting the occurrence of the market, i.e. desire, purchasing power, and behavior in the purchase (Chang, 2000).

Revitalization is an attempt to revitalize an area or part of a city that once lived but experienced a decline and degradation.

Factor analysis used in this research aims to reduce and analyze the factors that are used as an illustration of the factors affecting the performance of the supervision consultant on the time and quality of market revitalization work in Tulungagung District. This analysis produces information about the data structure of the performance of the supervision consultant on the time and quality of market revitalization work in Tulungagung District. The results of factor analysis on the 7 variables will be tested for its variables' feasibility to determine the correlation between variables or indicators. If the MSA value is $<0.5$, then it will be removed then recalculated until it has an MSA value $>0.5$ so that the factor of the value is worth to be analyzed further. Then, it will be extracted into several main factors that are smaller than the total number of indicators (Ghozali, 2006).

It aims to examine the questions relating to the factors affecting the performance of the supervision consultant on the time and quality of market revitalization work in Tulungagung District and to determine the most dominant factors affecting it. Thus, the analysis technique used is Path Analysis (Solimun and Rinaldo, 2006).

\section{METHODS OF RESEARCH}

Research is a scientific way to solve a problem and to penetrate the limits of human ignorance. Research activities are carried out by collecting and processing the existing facts so that they can be communicated by the researcher and the findings can be enjoyed and used for the benefit of humans.

Based on the method, this research includes the type of descriptive research which aims to obtain any factors affecting the performance of the supervision consultant on the time and quality of market revitalization work in Tulungagung District and to determine the most dominant factors affecting it.

This research applied survey method by collecting respondents' opinions, experiences and attitudes about the existing problems by taking primary data through questionnaires and secondary data from related institutions. Based on the factors affecting the performance of supervision consultant on the time and quality of market revitalization work in Tulungagung District, the factors that are assumed to affect the performance of the supervision consultant on the time and quality will be determined further by determining the indicators to be used as questions in which it will be measured in the form of a questionnaire.

The research setting is a market revitalization project in Tulungagung District in the fiscal year of 2015 .

Research Variables:

- Independent Variables (X) consist of: Understanding of Contract Documents and Understanding of Technical Specifications (X1), Interaction and Coordination Skills (X2), Commitment and Flexibility (X3), Adequacy of Resources (X4), Experience (X5), Capability (X6) and Motivation (X7).

- Dependent Variables (Y) consist of: Accurate Time (Y1) and Accurate Quality (Y2). 


\section{RESULTS AND DISCUSSION}

Validity Test Results. The validity test results explained that the Variables of Understanding of Contract Document and Understanding of Technical Specifications (X1), Interaction and Coordination Skills (X2), Commitment and Flexibility (X3), Adequacy of Resources (X4), Experience (X5), Capability (X6), and Motivation (X7) with the significance level $(\alpha)=0.05$ obtain a critical value $r_{\text {table }}$ of 0.308 (attachment 3 ) which means that the values of correlation coefficient of each factor are greater than $r_{\text {table. }}$ In addition, the $p$-value of each factor is smaller than $\alpha=0.05$. Therefore, it can be concluded that the items in the instrument on the Variables of Understanding of Contract Documents and Understanding of Technical Specifications (X1), Interaction and Coordination Skills (X2), Commitment and Flexibility (X3), Adequacy of Resources (X4), Experience (X5), Capability (X6), Motivation (X7) in this research are valid.

Reliability Test Results. The reliability test results produce the Cronbach's Alpha coefficient for each variable. All Cronbach's Alpha coefficients are greater than 0.6. Thus, based on this test, it can be concluded that the instrument used to measure the Variables of Understanding of Contract Document and Understanding of Technical Specifications (X1), Interaction and Coordination Skills (X2), Commitment and Flexibility (X3), Adequacy of Resources (X4), Experience (X5), Capability (X6), Motivation (X7) is reliable.

Table 1 - The Results of OLS of the First Equation

\begin{tabular}{llll}
\hline Independent Variables & Beta & $\mathrm{t}_{\text {count }}$ & Sig. $\mathrm{t}$ \\
\hline Understanding of Contract Documents and Understanding of Technical Specifications (X1) & 0.054 & 0.232 & 0.825 \\
Interaction and Coordination Skills (X2) & 0.235 & 2.338 & 0.026 \\
Commitment and Flexibility (X3) & 0.022 & 0.102 & 0.919 \\
Adequacy of Resources (X4) & 0.452 & 2.601 & 0.014 \\
Experience (X5) & 0.172 & 0.997 & 0.326 \\
Capability (X6) & 0.307 & 2.183 & 0.036 \\
Motivation (X7) & -0.033 & -0.033 & 0.974 \\
\hline $\mathrm{R}^{2}=0.700$ & & \\
$\mathrm{t}_{\text {table }}=2.035, \mathrm{~F}_{\text {table }}=2.365$ & & \\
$\mathrm{~F}_{\text {table }}=2.365$ & & \\
Dependent Variable = Time Target (Y1) & &
\end{tabular}

Source: SPSS Analysis, 2017.

Factor Analysis Results:

- The Variable of Understanding of Contract Documents and Understanding of Technical Specifications (X1) is formed by manifest variables consisting of: Lack of understanding on the contents of the contract documents (X1.1), Not studying the contents of the contract documents (X1.2), Lack of understanding on the contract documents (X1.3), and Lack of understanding on the shortcomings and advantages of the contract documents (X1.4).

- The Variable of Interaction and Coordination Skills (X2) is formed by manifest variables consisting of: Lack of Coordination (X2.1), the Absence of Coordination (X2.2), and Lack of Interaction (X2.3).

- The Variable of Commitment and Flexibility (X3) is formed by manifest variables consisting of: the Consultants do not work in accordance with the commitment (X3.1), the Commitment is not matched to the ability (X3.2), and It is frequent that the commitment is not fulfilled (X3.3).

- The Variable of Adequacy of Resources (X4) is formed by manifest variables consisting of: Limitations of the number of resources (X4.1), Limitations of the number of resources that have special skills (X4.2), frequent absence of the resources from the work site (X4.3), and lack of good coordination (X4.4).

- The Variable of Experience (X5) is formed by manifest variables consisting of: Lack of consultant experience (X5.1), Many workers have no work experience (X5.2), and experience of consultants is not balanced with the experience of the workers (X5.3) 
- The Variable of Capability (X6) is formed by manifest variables consisting of: Consultant labor with low educational background (X6.1), the workers are not equipped with SKA (X6.2), and SOP preparation is not optimal (X6.3).

- The Variable of Motivation (X7) is formed by manifest variables consisting of: Desire to get a large wage (X7.1) and Desire to get recognition (X7.2).

Path Analysis Results. The results of the OLS estimation of the first equation can be seen in Table 1.

The results of the OLS estimation of the second equation can be seen in Table 2 .

Table 2 - The Results of OLS of the Second Equation

\begin{tabular}{llll}
\hline Independent Variables & Beta & $\mathrm{t}_{\text {count }}$ & Sig. $\mathrm{t}$ \\
\hline Understanding of Contract Documents and Understanding of Technical Specifications (X1) & -0.234 & -1.408 & 0.169 \\
Interaction and Coordination Skills (X2) & 0.240 & 2.144 & 0.037 \\
Commitment and Flexibility (X3) & 0.114 & 0.759 & 0.453 \\
Adequacy of Resources (X4) & 0.528 & 4.024 & 0.000 \\
Experience (X5) & -0.107 & -0.891 & 0.380 \\
Capability (X6) & 0.390 & 2.385 & 0.023 \\
Motivation (X7) & 0.104 & 1.157 & 0.256 \\
Time Target (Y1) & 0.390 & 3.257 & 0.003 \\
\hline $\mathrm{R}^{2}=0.862$ & & &
\end{tabular}

$\mathrm{R}^{2}=0.862$

$t_{\text {table }}=2.037, F_{\text {table }}=2.306$

Dependent Variable $=$ Quality Target $(\mathrm{Y} 2)$

Source: SPSS Analysis, 2017.

\section{CONCLUSION AND SUGGESTIONS}

Based on the findings of the research and discussion described in the previous chapter, the following conclusions can be drawn:

Based on the F-test results, it was found that all factors of Understanding of Contract Document and Understanding of Technical Specifications (X1), Interaction and Coordination Skills (X2), Commitment and Flexibility (X3), Adequacy of Resources (X4), Experience (X5), Capability (X6), Motivation (X7) have an effect directly or indirectly and simultaneously on the time target with $F_{\text {count }}=10.986>F_{\text {table }}=2.365$ and quality target with $F_{\text {count }}=25.032>F_{\text {table }}=$ 2.306. However, individually, the factors that have significant effect on the time target are Interaction and Coordination Skills $(X 2)$ with $t_{\text {count }}=2.338>t_{\text {table }}=2.035$, Adequacy of Resources (X4) with $t_{\text {count }}=2.601>t_{\text {table }}=2.035$, and Capability $(X 6)$ with $t_{\text {count }}=2.183>t_{\text {table }}$ $=2.035$. In addition, the factors that have significant effect on the quality target are Interaction and Coordination Skills $(X 2)$ with $t_{\text {count }}=2.144>t_{\text {table }}=2.037$, Adequacy of Resources (X4) with $t_{\text {count }}=2.538>t_{\text {table }}=4.024$, Capability $(X 6)$ with $t_{\text {count }}=2.385>t_{\text {table }}=$ 2.037 , and Time Target $(Y 1)$ with $t_{\text {count }}=3.257>t_{\text {table }}=2.013$ on the Quality target $(Y 2)$; either directly and indirectly through Time Target (Y1).

The most dominant factor affecting the failure in achieving the time target and quality target directly or indirectly is the Adequacy of Resources (X4) with the value of the Standardized Coefficient $\beta$ of 0.452 and 0.528 respectively.

Strategies to improve the performance of supervision consultants so that the time and quality of the project can be met are:

The consultant must immediately increase the number of personnel, so that the project can be carried out in accurate time and quality.

The consultant must employ supervisors who have higher education, so they can carry out their duties in accordance with the provisions.

Before starting the implementation of the work, the consultant must be able to ensure that all personnel stationed in the field can coordinate well in order to achieve the time and quality targets.

Suggestions:

To improve the performance of the supervision consultant on the time and quality of project implementation, the consultant must employ experts who are proportional in carrying out their duties in the field. 
The supervision consultant must establish good communication with the executors from the contractor party in order to achieve good work results and time and quality of the implementation based on the schedule.

The owner must give an admonition to the consultant who does not carry out the duties properly and in accordance with the provisions of the contract.

Further research is expected to add other variables such as the variables of discipline, quality control, and supervision and pay more attention to those indicators.

\section{REFERENCES}

1. Arditi, D., \& Patel, B. K. (1989). Impact analysis of owner-directed acceleration. Journal of Construction Engineering and Management, 115(1), 144-157.

2. Chan, A. P., \& Chan, A. P. (2004). Key performance indicators for measuring construction success. Benchmarking: an international journal, 11(2), 203-221.

3. Chang, E. C., Cheng, J. W., \& Khorana, A. (2000). An examination of herd behavior in equity markets: An international perspective. Journal of Banking \& Finance, 24(10), 16511679.

4. Churchill, G. A., \& lacobucci, D. (2006). Marketing research: methodological foundations. New York: Dryden Press.

5. Cowan, L. T., Van Wagenen, S. A., Brown, B. A., Hedin, R. J., Seino-Stephan, Y., Hall, P. C., \& West, J. H. (2013). Apps of steel: are exercise apps providing consumers with realistic expectations? A content analysis of exercise apps for presence of behavior change theory. Health Education \& Behavior, 40(2), 133-139.

6. Ghozali I. (2006), Aplikasi Analisis Multivariate Dengan Program SPSS, Badan Penerbit Universitas Diponegoro, Semarang.

7. Nugraha, P., Natan, I., \& Sutjipto R. (1985). Manajemen Proyek Konstruksi Jilid I dan II, Penerbit Kartika Yudha Surabaya

8. Slater, S. F., Mohr, J. J., \& Sengupta, S. (2010). Market orientation. Wiley International Encyclopedia of Marketing.

9. Soeharto, I. (2001). Manajemen Proyek Dari Konseptual Sampai Operasional. Erlangga. Jakarta

10. Solimun, N., \& Rinaldo, A. A. (2006). Permodelan Persamaan Struktural Pendekatan PLS dan SEM. Modul Pelatihan Aplikasi Software Smart PLS dan AMOS, Fakultas MIPA dan Program Pascasarjana, Universitas Brawijaya Malang. 